\title{
Integration of Human Resource Information System to DSS, CMS and other applications to increase productivity
}

\author{
Dr Parimalendu \\ Bandyopadhyay \\ Assistant Prof, Raiganj Univ. \\ College
}

\author{
Mr. Joydeep Chowdhury \\ Associate Project, Cognizant
}

\author{
Gunamoy Hazra \\ Department of Bussiness \\ Administration, B.B College
}

\begin{abstract}
:
Human Resources Management also deal with the facilities and requirements the Human Workforce are availing and need for their working process and carrier growth. It used to act as a bidirectional process flow which increase the "Workforce" and "Senior Management" and collaborate everybody's requirements in a solution space and help to provide a better and value added service or outcome to customer or client of the organization.
\end{abstract}

To make a human resource department more effective and efficient new technologies are now being introduced on a regular basis so make things much simpler and more modernized. One of the latest human resource technologies is the introduction of a Human Resources Information System.
This integrated system is designed to help provide information used in HR decision making such as administration, payroll, recruiting, training, and performance analysis.

\section{Need of Integration of "Human Resource Information System":}

Human Resource Information System has lots of "Process Orientation" that is really tuff for human to track "Status" and "Record" of each request generated by or for any particular employee. Employee are the biggest resource for any organization. The problems with colloquial "Human Resource Management" system were:

\begin{tabular}{|l|l|}
\hline Disadvantages of Manual HR Process & Description \\
\hline Difficult To track "Escalation Matrix": & $\begin{array}{l}\text { A large organization contains a large number of employee. The manual } \\
\text { human resource management were unable to manage the request coming } \\
\text { from each employee. So, to resolve a request it was taking much more time } \\
\text { which let to unsatisfactory working environment. }\end{array}$ \\
\hline Difficult to manage integrated process flow: & $\begin{array}{l}\text { The manual human resource management requires lots of paper work and } \\
\text { people, effort to "Track The Flow of each process" which also increases } \\
\text { the cost, "Control the flow of each process" and "Record and search the } \\
\text { flow of each process". }\end{array}$ \\
\hline $\begin{array}{l}\text { Unable to get "Bidirectional" and "Deep-dive } \\
\text { Hierarchical" Performance management": }\end{array}$ & $\begin{array}{l}\text { The poor process flow restrict the entire system to do "Bi-directional" such } \\
\text { as 360 degree performance management. So, the unsatisfactory work } \\
\text { environment for employee were increasing and management were unaware } \\
\text { about their own flows. }\end{array}$ \\
\hline $\begin{array}{l}\text { Difficult to implement the "Career Plan" and } \\
\text { Training Program" }\end{array}$ & $\begin{array}{l}\text { Since less interaction with "Supervisor" and poor flow of information } \\
\text { employee were unable to find and fix career plan and training program } \\
\text { which is best suited for his/her. }\end{array}$ \\
\hline $\begin{array}{l}\text { Poor "Document Management System" and } \\
\text { Massaging Services: }\end{array}$ & $\begin{array}{l}\text { the document the employee used to submit manually and if anyone such as } \\
\text { "Supervisor" want to see these they has to go to HR department. If } \\
\text { department lost the document employee again has to submit that. The } \\
\text { employee never get any alert for any emergency or any "Process State } \\
\text { Related" alert. }\end{array}$ \\
\hline
\end{tabular}

\section{How Productivity of HRIS will be enhanced by including the following applications:}

The "Integrated Human Resource Information System" contains lots of module and for convenience of customer this modules can be purchased alone without purchasing the entire solution package. This modules have great flexibility that according to business need it can be customaries and "Rule base modeling "can also be implemented. More over these modules can be publish and integrated through web. For example, many organization now a day maintaining their portal through any "Portal Collaboration" software such as "SharePoint", "File Net" etc. the HRMS software such as "PeopleSoft", SAP HRIS or the modules can be integrated with the Portals.A general "Human Resource Management" contains the following modules: 


\begin{tabular}{|c|c|}
\hline Modules of HRMS & Description \\
\hline Organization Management: & $\begin{array}{l}\text { HRIS can able to structured the organization such as Company, Location, Department, Designations, } \\
\text { Employee Group and Organization Change such as Resignation, Termination, Transfer, Promotion etc. }\end{array}$ \\
\hline Employee Information Management: & $\begin{array}{l}\text { HRIS used to store all information of an employee such as employee master, academic information, } \\
\text { organization information, past experiences, employee leave information, JD's, Training information, } \\
\text { pay structure information(on demand), passport details(on demand), nominee details(on demand), } \\
\text { Complete Bank Details, Details to Configure "Reporting Tool". For e.g. a fortune } 500 \text { company has } \\
\text { introduced "Information gathering about new joinee" through "Content Management System and } \\
\text { HRIS" which helps to capture every detail before joining of new work force. }\end{array}$ \\
\hline Recruitment or Staffing: & $\begin{array}{l}\text { Candidate information form at entry level, advanced level, whole recruitment cycle--MPR (Man } \\
\text { Power Request) Or Staff Requisition, Man Power planning according to estimated budget, Man } \\
\text { approval at different levels, recruitment expenses, consultant interface(on demand). For e.g. a fortune } \\
500 \text { company has introduced "Employee Self Service" through "Content Management System and } \\
\text { HRIS" which helps to recruit resources for any specific projects. On year 2010-11 referral program has } \\
\text { recruited 63\% of new work force. }\end{array}$ \\
\hline $\begin{array}{l}\text { Performance Management and Man } \\
\text { Power Development Or Training: }\end{array}$ & $\begin{array}{l}\text { Depending on performance of an employee the changed that will be happened in employees' profile } \\
\text { will be reflected across the system even in different module such as "Employee Detail", "Payroll } \\
\text { Management", "Insurance Management" etc. The performance management can de different type such } \\
\text { as: 1] } 360 \text { degree: The evolution based on comments of "Supervisor", "Client", "Group" and some } \\
\text { time external entities.2] } 180 \text { degree: The evolution based on comments of "Supervisor" and Client. } \\
\text { The "Training Management" module contains the following step which use to execute as work flow: } \\
\text { 1] Training budget 2] Training Application and approval 3] Training programs 4] Training evaluation } \\
\text { 5] Training Attendance. } \\
\text { For e.g. world largest bank has introduced a site through their "Content Management Portal", } \\
\text { integrated with HRIS which is dedicated for "Project specific training" for employee. For last year it } \\
\text { has dragged } 84 \% \text { of employees to organize and capture their training detail. }\end{array}$ \\
\hline $\begin{array}{l}\text { Employee Self Services and Manager } \\
\text { Self Services and Organization } \\
\text { Climate Survey: }\end{array}$ & $\begin{array}{l}\text { In Employee Self Service employee can put all the services which the employee can make use. By } \\
\text { using "Employee Self Service" employee can manage the followings: 1] HR Help Desk 2] Employee } \\
\text { Document 3] Job Information. } \\
\text { Managerial Self Service employee can put all the services which the manager can use for employee. } \\
\text { By using "Managerial Self Service" employee can manage the followings: 1] Career Planning 2] } \\
\text { Repartee's Information 3] Separation. } \\
\text { For e.g. a fortune } 500 \text { company has introduced "Employee Self Service" through "ORACLE APPS" } \\
\text { which sustain their employee retention rate from } 78 \% \text { to } 92 \% \text { from year } 2000 \text { to } 2012\end{array}$ \\
\hline Employee Help Desk/Suggestions and & Through this module employee can escalate any issue or queries to "Human Resource" department. \\
\hline
\end{tabular}




\begin{tabular}{|l|l|}
\hline Opinion Polls & $\begin{array}{l}\text { For e.g. a Fortune } 500 \text { company implement the "Help Desk Portal" to raised employees' concern used } \\
\text { to receive an average of } 4000 \text { request every day. }\end{array}$
\end{tabular}

\section{Market condition of "Human Resource Information System"-Key Findings}

The market for "Human Resource Information System" is growing very fast. This decade every organization are trying to implement an effective and integrated "Human Resource Management System". The Survey report says that the rate of growth of "Human Resource Market" around 3\% in 2006, around 5.6\% in 2007 and in 2008-2009 it grows was more than 8 percent. The total market capitals for HRIS are around $\$ 80$ billion in 2008-09. In 2010-11 the growth rate become 9.2 percent and market capital become $\$ 110$ billion where the "Integration of HRIS" with other applications plays an important role.

\begin{tabular}{|l|l|l|}
\hline Technology/Tool & Growth Rate in 2008-2009 & Growth rate in 2010-2011 \\
\hline Enterprise Content Management System & 8.2 & 7 \\
\hline Human Resource Management Software & 8 & 9.2 \\
\hline Customer Relationship Management & 6.7 & 6.5 \\
\hline Enterprise Resource Planning & 2.86 & 3.7 \\
\hline Web Technology & 2.2 & 2.7 \\
\hline Supply Chain Management & 1.9 & 1.6 \\
\hline
\end{tabular}

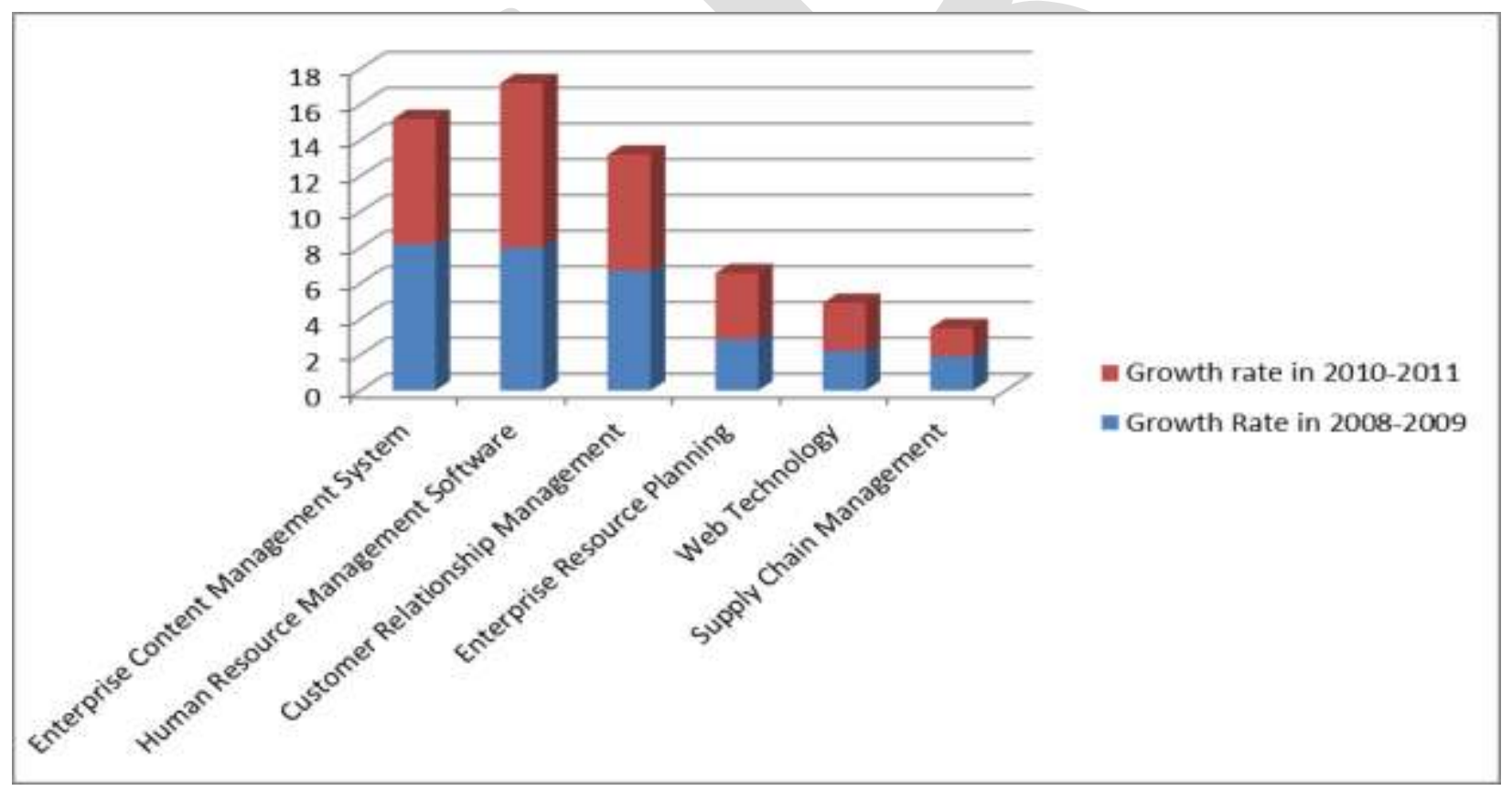

\section{Data analysis of Integrated HRIS:}

How integrated HRIS with CMS, DSS and other systems increase the productivity- this can be measured in several factors such as "Employee Apprisal Calculation", "Employee Project Performance", ,"Certification", " Reimbursement ", "Project Allocation" etc. There are three major HRIS software vendors such as Peoplesoft, SAP, Lawson and Korson upon which this integration has been measured. The main CMS Microsoft SharePoint has been considered for this integration. The following fig. shows how the HRIS product increase the productivity after integration. 


\begin{tabular}{|c|c|c|c|}
\hline HRIS Product & $\begin{array}{l}\text { Average time reduction to } \\
\text { information } \\
\text { between CMS, DSS and other } \\
\text { applications in percentage }\end{array}$ & $\begin{array}{l}\text { Productivity before integration } \\
\text { in scale of factors such as } \\
\text { "Employee } \\
\text { Calculation", Appraisal } \\
\text { Project } \\
\text {,"Eertification", Performance" } \\
\text { "Reimbursement", "Project } \\
\text { Allocation" and others }\end{array}$ & $\begin{array}{l}\text { Productivity after } \\
\text { integration in scale of } \\
\text { factors such as } \\
\text { "Employee Appraisal } \\
\text { Calculation", } \\
\text { "Employee Project } \\
\text { Performance" } \\
\text { "Certification", } \\
\text { "Reimbursement", } \\
\text { "Project Allocation" } \\
\text { and others }\end{array}$ \\
\hline Peoplesoft & $92 \%$ & $53 \%$ & $95 \%$ \\
\hline SAP & $77 \%$ & $45 \%$ & $88 \%$ \\
\hline LAWSON & $43 \%$ & $22 \%$ & $44 \%$ \\
\hline KRONOS & & $17 \%$ & $25 \%$ \\
\hline
\end{tabular}

\section{Productivity increase of organization by integrated HRIS}

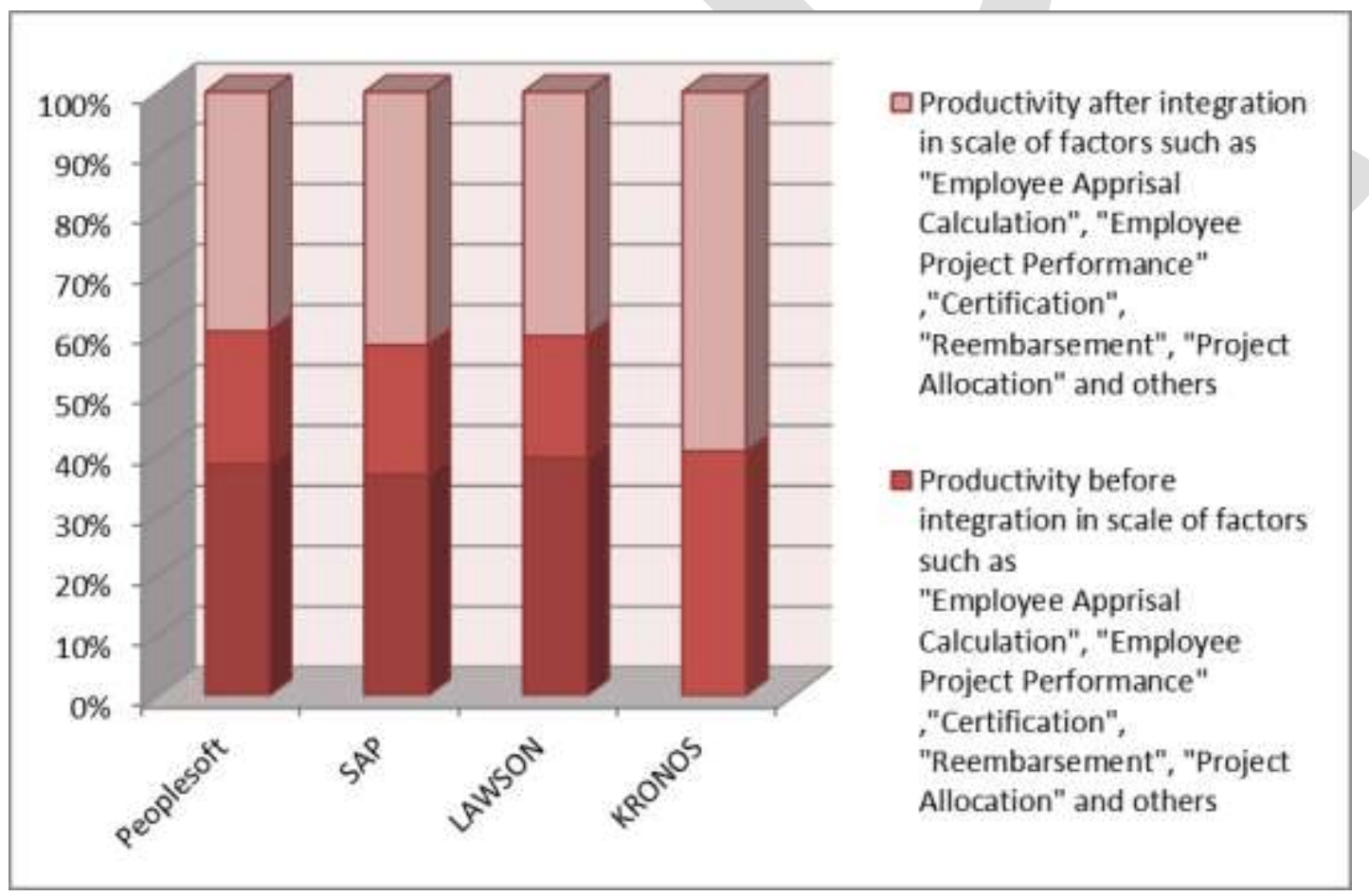

\section{Conclusion:}

The Integrated HRIS function includes a variety of activities, and key among them is deciding what staffing needs you have and whether to use independent contractors or hire employees to fill these needs, recruiting and training the best employees, ensuring they are high performers, dealing with performance issues, and ensuring your personnel and management practices conform to various regulations. Activities also include managing your approach to employee benefits and compensation, employee records and personnel policies. Integration with CMS, DSS and other applications with HRIS can increase the productivity by $28.75 \%$ [(Productivity after integration- Productivity after integration)/Number of HRIS Product], save time to complete a workflow up to $34 \%$. Its can helps to reduce the manual engagement and save time during information sharing up to 29\%. Currently in 2011-12 in Indian IT sectors more or less all organizations are using HRIS such as People soft, LAWSON SOFTWARE, SAP, KRONOS, SAGE SOFTWARE, CERIDIAN, MANGROVE, IEMPLOYEE etc. By integrating with other applications these increase productivity and reduce the time to information flow.

\section{Research Methodology:}


During this period we a came to know what process are use to implement integration of HRIS with CMS, DSS and other applications and what tools are being used. What are the phases of "Integrated Human Resource Information System. Our References are from Asian Paint, PeopleSoft, Nissan Middle East, ABB AG, Ford Motors etc. In this research the data is from secondary source and the methodologies are "Content analysis" and "Industrial Research".

\section{Reference:}

- ORACLE PEOPLE SOFT STORE: Prepared by PeopleSoft group

2012:http://estore.salesquest.com/CRUSH-

reports/peoplesoft-customer-intel-list accessed 26/5/2012

- Kathryn Thory :2008: The internationalisation of HRM through reverse transfer: two case studies of French multinationals in Scotland; http://www3.interscience.wiley.com/journal/1194 09958/abstract ; accessed on 1/11/2011

- Markus Pudelko ;2006: A comparison of HRM systems in the USA, Japan and Germany in their socio-economic context ; http://www.blackwellsynergy.com/doi/full/10.1111/j.17488583.2006.00009.x

$1 / 12 / 2011$
- Michael J. Kavanagh, Richard D. Johnson, Mohan Thite - 2011; Human Resource Information Systems: Basics, Applications http://books.google.co.in/books?id=yDerMyZSbkC\&dq=hris\&hl=en\&sa $=X \& e i=Z 7 H m T-$ G8ElbJrQeMlsmJCQ\&ved=0CDwQ6AEwAA accessed on 5/4/2012

- Mike W. Peng - 2010; Global Business; http://books.google.co.in/books?id=1gl1JjL96UAC\& pg=PA463\&dq =hris\&hl=en\&sa $=X \& e i=Z 7 H m T-$ G8ElbJrQeMlsmJCQ\&ved=0CFQQ6AEwBA\#v=onepa ge $\& q=h r i s \& f=f a l s e ;$ accessed on 2/2/2012

- Deborah DeWolfe Waddill, Michael J. Marquardt 2011 ; The e-HR Advantage;http://books.google.co.in/books?id=jrl8 $x q 33 z 1 s C \& p g=P T 74 \& d q=h r i s \& h l=e n \& s a=X \& e i=Z 7 H$ mT-G8ElbJrQeMlsmJCQ\&ved=0CFoQ6AEwBQ; Accessed on 6/6/2012

- $\quad$ SAP ERP Human Capital Management: Prepared by SAP ERP group on 2012; http://www.sap.com/solutions/businesssuite/erp/hcm/index.epx accessed on 20/5/2012

- PeopleSoft Enterprise Applications: Prepared by PeopleSoft group; 2011 http://www.oracle.com/us/products/applications/ peoplesoft-enterprise/index.htm accessed on 20/11/2011 